\title{
The Ability to Interact with Schizophrenic Patients through Socialization Group Activity Therapy
}

\author{
Jek Amidos Pardede ${ }^{1}$, Arya Ramadia ${ }^{2}$ \\ ${ }^{1}$ Nursing Study Program, Sari MutiaraIndoensia University, North Sumtra Indonesia, \\ ${ }^{2}$ Nursing Study Program, STIKes Al Insyirah Pekanbaru, Riau, Indonesia
}

\begin{abstract}
Social isolation is a disorder of interpersonal relationships that occurs due to an inflexible personality, which causes maladaptive behavior and interferes with one's function in relationships. One of the nursing actions for schizophrenic patients with social isolation is Socialization Group Activity Therapy. Socialization Group Activity Therapy is an effort to facilitate socialization skills in schizophrenia patients with social relationship problems. The purpose of this study was to determine the effect of socialization group activity therapy on the ability to interact with schizophrenic clients. The research design used one group pre-post test design, the sampling technique used was purposive sampling and the total sample was 21 respondents. The ability to interact socially was measured using a questionnaire sheet before and after therapy using a paired sample test. The analysis showed that there was a significant effect with $p=0.014(p<0.05)$. The conclusion is that Socialization Group Activity Therapy is one of the effective therapies to improve the interaction ability of schizophrenic patients.
\end{abstract}

Keywords: Socialization Group Activity Therapy, Social Interaction, Schizophrenia.

\section{Introduction}

Schizophrenia is a group of psychotic reactions that affect various areas of individual functioning, including thinking, communicating, accepting, interpreting reality, feeling, and showing emotions because schizophrenia is a chronic, severe, and disabling disease, a brain disorder characterized by chaotic thoughts, delusions, hallucinations, and strange behavior ${ }^{1,2}$. Negative symptoms include difficulty starting a conversation, a dull or flat effect, reduced motivation, reduced attention, passivity, apathy, and social withdrawal and discomfort ${ }^{3}$. According to ${ }^{4}$.Negative symptoms are responsible for a significant proportion of the disability linked with schizophrenia. They are more closely related to prognosis than positive symptoms. Interest in negative symptoms of patients with schizophrenia is now greater than before, paralleling increasing attention to the functional influence of negative symptoms ${ }^{5}$. Schizophrenia is a

Corresponding author:

Jek Amidos Pardede

jekpardedemi@rocketmail.com severe mental disorder that affects as many as 1 in 100 people at some point in their lives ${ }^{6}$.

According to ${ }^{7}$ that the behaviors that often appear in schizophrenic clients are lack of motivation (81\%), social isolation (72\%), poor eating and sleeping behavior $(72 \%)$, difficulty completing tasks (72\%), difficulty managing finances (72\%), an appearance that is not neat and clean (64\%), forgetting to do something (64\%), lack of attention from others (56\%), and not regularly taking medication (40\%). Social isolation refers to the objective absence or paucity of contacts and interactions between a person and a social network ${ }^{8}$.

Social isolation as a negative symptom in schizophrenia is used by patients to avoid other people so that unpleasant experiences in dealing with other people do not happen again. Withdrawal is used by patients to avoid other people so that unpleasant experiences in dealing with other people do not happen again. Thus social isolation is an individual's failure to interact with others as a result of unpleasant experiences as a threat to the individual. Behaviors that are often displayed by clients of social isolation are showing withdrawal, 
uncommunicative, trying to be alone, cool with their thoughts and themselves, no eye contact, sadness, dull affection, hostile behavior, expressing feelings of loneliness or being rejected, difficulty building relationships in their environment, avoiding other people and express feelings of not being understood by others ${ }^{9,10}$. Perceived social isolation, known more colloquially as loneliness, was characterized in early scientific investigations as "chronic distress without redeeming features". Recent research suggests that the social pain of loneliness evolved as a signal that one's connections to others are weakening and to motivate the repair and maintenance of the connections to others that are needed for our health and well-being and for the survival of our genes ${ }^{11,12}$.

Patients with problems lack social skills, cannot communicate with others effectively, experience difficulty in making friends, are able to solve problems, find and keep jobs, which is the reason they isolate themselves from society. Poor social skills are closely related to recurrence of disease and patient return to the hospital, this has been reported as an important factor affecting prognosis ${ }^{13}$. A social skills training program can help them return to society. This training has been shown to be effective in increasing social adaptability, reducing psychiatric symptoms, thereby reducing rehospitalization rates, in addition to increasing patient self-esteem ${ }^{14}$.

One therapy modality that can help build relationships with other people is Group Activity Therapy, with group activity therapy, patients are able to socialize, know the context of reality, channel energy, increase self-esteem. This is in accordance with the objectives of Group Activity Therapy, namely to socialize and increase reality testing, to increase awareness of the relationship between emotional reactions and defensive actions or behavior or channel emotions constructively and improve cognitive and affective functions.

The results of the initial survey conducted at Mental Hospital in Medan found that in 2020 as many as 13,065 people had schizophrenia. The results of interviews and observations during Group Activity Therapy for up to 4 sessions with 9 schizophrenic patients. Schizophrenic patients who attended Group Activity Therapy seemed happy to participate in Group Activity Therapy and were able to participate in these activities. During Group Activity Therapy there is good cooperation between patients. However, there were still 2 patients who gave a passive attitude, seemed silent, and less happy with the Group Activity Therapy activities. This shows that the implementation of Group Activity Therapy is still not optimal, making these patients less socializing with other groups or patients and less interacting with other groups and patients. This problem makes researchers interested in examining whether there is an effect of therapy on the patient's ability to socialize properly when the patient follows all the sessions given.

\section{Research Methods}

This study used a one-group pre-post test design which aims to explain the effect of Socialization Group Activity Therapy on the interaction ability of schizophrenic clients. The population is the subject of research. The population in this study were all schizophrenia patients, amounting to 922 people. The sample taken in this study were treated with schizophrenic patients. The sampling technique used purposive sampling, namely the technique of determining the sample according to what is desired so that the sample can represent the characteristics of the population of 19 samples. The sampling technique in this study was determined with a consideration of criteria that focused on social isolation patients whose criteria were as follows: Schizophrenic patients with nursing problems social isolation, cooperative and able to communicate, able to answer questions well, and willing to participate in socialization group activity therapy To complete all sessions, the researcher used the Paired Sample Test statistical test to analyze the difference in the average score of the ability to interact with respondents before and after the intervention. The significant test of the calculation results is to compare the results of the calculation of significance (p) for the "level of significance" ) $=5 \%(0.05)$ or $95 \% \mathrm{CI}$ (Confidence Interval). If the p-value $<\alpha(0.05)$ means that the Socialization Group Activity Therapy has a significant effect on the ability to interact with. 


\section{Results}

Table 1: Characteristics of Schizophrenic Patients With Social Isolation Problems

\begin{tabular}{|c|c|c|}
\hline Characteristics & $\mathbf{n}$ & $\%$ \\
\hline Age & & \\
\hline 20-29 years & 3 & 14.3 \\
\hline $30-40$ years & 14 & 66.7 \\
\hline 41- 50 years & 4 & 19.0 \\
\hline Gender & & \\
\hline . $\quad$ Male & 18 & 85.7 \\
\hline Female & 3 & 14.3 \\
\hline Education & & \\
\hline . $\quad$ Junior High School & 3 & 14.3 \\
\hline Senior High School & 18 & 85.7 \\
\hline Marital status & & \\
\hline . $\quad$ Married & 4 & 19.0 \\
\hline S Single & 16 & 76.2 \\
\hline Widower widow & 1 & 4.8 \\
\hline
\end{tabular}

In Table 1, it can be seen that the majority of respondents are 30-40 years old (66.7\%), 18 people are male (85.7\%), 18 respondents have high school education background (85.7\%), and most of the respondents are not married $(76.2 \%)$.

Table 2 Analysis of Changes in the Interaction Ability of Schizophrenic Patients Before and After Socialization Group Activity Therapy

\begin{tabular}{|l|l|l|l|l|}
\hline $\begin{array}{l}\text { The ability to interact with } \\
\text { schizophrenic patients }\end{array}$ & Mean & $\mathbf{n}$ & St. Deviation & Std. Error mean \\
\hline $\begin{array}{l}\text { The ability to interact with } \\
\text { schizophrenic patients before } \\
\text { socialization group activity therapy }\end{array}$ & 2.00 & 21 & .775 & 0.169 \\
\hline $\begin{array}{l}\text { The ability to interact with } \\
\text { schizophrenic patients after } \\
\text { socialization group activity therapy }\end{array}$ & 2.48 & 21 & .512 & 0.112 \\
\hline
\end{tabular}

In Table 2, it can be seen that there is a change in the ability to interact with schizophrenic clients before and after being given socialization group activity therapy, with an average change in the ability to interact with schizophrenic clients before socialization group activity therapy (Mean $=2.00$ and $\mathrm{SD}=.775)$, and the average changes in the ability to interact with schizophrenic clients after socialization group activity therapy (Mean $=2.48$ and SD. 512). 
Table 3: Effectiveness of Socialization Group Activity Therapy on Interaction Ability of Schizophrenic Patients

\begin{tabular}{|l|l|l|l|l|l|l|l|l|}
\hline \multirow{2}{*}{$\begin{array}{l}\text { The ability to interact } \\
\text { with schizophrenic } \\
\text { patients }\end{array}$} & Mean & St.deviation & SE & Lower & Upper & T & Df & P \\
\cline { 4 - 5 } & & & & & & & & \\
\hline $\begin{array}{l}\text { The ability to interact } \\
\text { with schizophrenic } \\
\text { patients before and } \\
\text { after being given } \\
\text { social group activity } \\
\text { therapy }\end{array}$ & -476 & .814 & .178 & -.847 & -.106 & -2.682 & 20 & 0.014 \\
\hline
\end{tabular}

In Table 3, it can be seen that there is a significant difference between the ability to interact with respondents before being given social group activity therapy and the ability to interact after being given social group activity therapy from the Paired Sample Test results found $\mathrm{p}=0.014(\mathrm{p}<0.05)$.

\section{Discussion}

\section{Changes in the ability to interact before and after the intervention}

The results showed that the mean interaction ability of the respondent who had schizophrenia before the intervention was mean $=2.00$ and $\mathrm{SD}=0.77$. Meanwhile, the ability of respondents with schizophrenia increased in socializing after attending group activity therapy (mean $=2.48 ; \mathrm{SD}=0.51$ ). These results indicate that there is a change in the ability to interact with respondents before and after the intervention.

Socialization group activity therapy is an effort to facilitate the socialization skills of a number of clients with social relationship problems, which aims to improve social relations in the group gradually, where patients can introduce themselves, are able to get acquainted with group members, are able to converse with group members, are able to convey and discuss conversational topics and be able to convey and discuss personal problems to others ${ }^{15}$.

The assumption of the researcher, this ability is due to the continuous process of implementing Socialization Group Activity Therapy. In the group, there is a dynamic of interacting and influencing each other so that other respondents are stimulated to carry out what was taught and what other respondents have succeeded in doing. This is in accordance with the theory that the advantage of group therapy is that it can reduce feelings of isolation, differences, and increase clients to participate and exchange ideas and problems with other people or groups. In addition, it also provides opportunities for patients to be able to receive feedback from others and to learn various ways to solve other people's problems.

Socialization Group Activity Therapy on Interaction Ability of Schizophrenic Clients

Based on the results of research on the effect of Socialization Group Activity Therapy on the socialization skills of respondents assessed using the Paired Sample Test statistical test, the calculated value of $p=0.014(p<0.05)$. The results of this study indicate that there is an effect of Socialization Group Activity Therapy on the socialization ability of respondents before and after the intervention. The results of this study indicate that respondents experienced problems in interacting with other people before being given the intervention. This is due to the absence of action or stimulus that can change maladaptive behavior patterns and a less therapeutic environment such as too many patients in the treatment room and the patient's lack of ability to interact with other clients. In general, social isolation patients feel good about their world and alone. According to ${ }^{16}$, Humans are social beings who cannot be separated from a condition called interaction and always have mutual relations and influence with other humans in order to meet their needs and sustain their lives.

The results of this study are consistent with the research of ${ }^{17}$ which shows that there is a significant 
effect of socialization group activity therapy on social interaction skills $(p=0.00 ; p<0.05)$. Socialization group activity therapy is one of the nursing interventions for patients with social isolation nursing problems. Through the process of socialization group activity therapy, patients are trained to interact socially by getting to know other people, chatting, expressing their feelings to others. In the group, there is a dynamic of interacting and influencing each other so that other respondents are stimulated to carry out what was taught and what other respondents have succeeded in doing. This is in accordance with the theory that the advantage of group therapy is that it can reduce feelings of isolation, differences, and increase clients to participate and exchange ideas and problems with others. In addition, it also provides opportunities for clients to be able to receive feedback from others and to learn various ways of solving problems and can help solve other people's problems ${ }^{18}$.

The effect resulting from the activity of socialization group activity therapy on the improvement of the respondent's socialization skills is because the socialization group activity therapy is an effort to facilitate the socialization skills of a number of clients with social relationship problems. Schizophrenic patients experience disturbances in daily functions, both in work, social relationships, and self-care habits. However, intensive handling, in the form of providing various exercises or therapies, such as occupational therapy, social skills training, and so on for schizophrenics, has been shown to improve social skills and suppress their social disability.Patients with problems lacking social skills, unable to communicate with others effectively, not making friends easily, or effectively solving their problems, difficulty finding and keeping jobs, will further isolate themselves from society. Poor social skills are closely related to recurrence of disease and client return to the hospital, these have been reported as important factors influencing prognosis. A program of training social skills for patients with social isolation problems and ultimately successfully helping them return to society.

The assumption of researchers that the patient's ability is due to the process of implementing continuous socialization group activity therapy. In the group, there is a dynamic of interacting and influencing each other so that other respondents are stimulated to carry out what was taught and what other respondents have succeeded in doing. This is consistent with the theory that the advantage of group therapy is that it can reduce feelings of isolation and increase patients to participation and exchange of thoughts and problems with others. In addition, it also provides opportunities for patients to be able to receive feedback from others and can learn various ways of solving problems, and can help solve other people's problems. It can be argued that in dealing with the fear and insecurity of people with schizophrenia, a therapeutic condition is needed which supports an orientation to reality or reality and which encourages their interest in relating to other people. Group intervention supports the members' social relationships with each other, which is supported by a therapist who can provide their socialization experience.

\section{Conclusion}

Mean interaction ability of schizophrenic patients before socialization group activity therapy (Mean = 2.00 , SD $=.775$ ). The average interaction ability of schizophrenic patients after socialization group activity therapy (Mean $=2.48, \mathrm{SD}=.512$ ) and the Paired Sample Test results showed that there was a significant effect on the ability to interact with schizophrenia patients before and after being given socialization group activity therapy, the $p$-value was obtained. $=0.014(p<0.05)$.

Ethical Clearance- Taken from ethical committee of institute: Sari Mutiara Indonesia University

\section{Source of Funding- Self.}

\section{Conflict of Interest- Nil.}

\section{References}

1. Rhoads J. Clinical consult for psychiatric mental health care. Springer Publishing Company; 2010 Oct 25.

2. Pardede JA, Hamid AY, Putri YS. Application of Social Skill Training using Hildegard Peplau Theory Approach to Reducing Symptoms and the Capability of Social Isolation Patients. JurnalKeperawatan. 2020 Jun 5;12(3):327-40.

3. Videbeck, S, L,. Psychiatric Mental Heath Nursing. 4th ed. Philadhelpia: Lippincott Williams and Wilkins. 2011

4. Vrbova K, Prasko J, Holubova M, Slepecky M, Ociskova M. Positive and negative symptoms in 
schizophrenia and their relation to depression, anxiety, hope, self-stigma and personality traits-a cross-sectional study. Neuroendocrinology Letters. 2018 Jan 1;39(1):9-18.

5. Remington G, Foussias G, Fervaha G, Agid O, Takeuchi H, Lee J, Hahn M. Treating negative symptoms in schizophrenia: an update. Current treatment options in psychiatry. 2016 Jun;3(2):13350 .

6. Crawford MJ, Killaspy H, Barnes TR, Barrett B, Byford S, Clayton K, Dinsmore J, Floyd S, Hoadley A, Johnson T, Kalaitzaki E. Group art therapy as an adjunctive treatment for people with schizophrenia: multicentre pragmatic randomised trial. Bmj. 2012 Feb 28;344.

7. Stuart GW, Laraia MT. Principles and Practice of Psychiatric Nursing. 8th ed. Philadelphia: Mosby. 2005:15-49.

8. Gardiner C, Geldenhuys G, Gott M. Interventions to reduce social isolation and loneliness among older people: an integrative review. Health \& social care in the community. 2018 Mar;26(2):147-57.

9. Herdman TH, editor. Nursing Diagnoses 20122014: Definitions and Classification. John Wiley \& Sons; 2012.

10. Pardede JA. The Implementation of Family Tasks with The Frequency of Recurrence of Social Isolation Patients. Mental Health. 2017;4(2).

11. Cacioppo JT, Patrick W. Loneliness: Human nature and the need for social connection. WW Norton \& Company; 2008 Aug 17.
12. Cacioppo JT, Hawkley LC, Norman GJ, Berntson GG. Social isolation. Annals of the New York Academy of Sciences. 2011 Aug;1231(1):17.

13. Seo JM, Ahn S, Byun EK, Kim CK. Social skills training as nursing intervention to improve the social skills and self-esteem of inpatients with chronic schizophrenia. Archives of psychiatric nursing. 2007 Dec 1;21(6):317-26.

14. Heinssen RK, Liberman RP, Kopelowicz A. Psychosocial skills training for schizophrenia: lessons from the laboratory. Schizophrenia bulletin. 2000 Jan 1;26(1):21-46.

15. Keliat BA \&Akemat. Model praktikkeperawatanpr of esionaljiwa. Jakarta: EGC. 2012.

16. Damanik RK, Pardede JA, Manalu LW. TerapiKognitif Terhadap Kemampuan Interaksi PasienSkizofrenia DenganIsolasiSosial. JurnalIlmu Keperawat andan Kebidanan. 2020 Jul 25;11(2):226-35.

17. Hasriana, H., Nur, M., \&Anggraini, S. The effect of socialization group activity therapy on social skills in social isolation clients with withdraw at the Special Hospital for South Sulawesi Province. .JurnalllmiahKesehatan Diagnosis, 2013:2(6), 7479.

18. Jones L, Brazel D, Peskind ER, Morelli T, Raskind MA. Group therapy program for African-American veterans with posttraumatic stress disorder. Psychiatric Services. 2000 Sep;51(9):1177-9. 